\title{
Faktor-Faktor yang berpengaruh pada Keberlanjutan Usaha Biro Jasa Perjalanan Haji dan Umrah
}

\author{
Hendi Prihanto \\ Program Studi Akuntansi, Universitas Prof. Dr. Moestopo (Beragama) \\ Jl. Hang Lekir I No. 8 Gelora, Tanah Abang, Jakarta Pusat, Indonesia \\ hendiprihanto@dsn.moestopo.ac.id \\ Prisila Damayanti* \\ Program Studi Akuntansi, Institut Bisnis dan Informatika Kosgoro 1957 \\ Jl. M. Kahfi II No. 33, Srengseng Sawah, Jagakarsa, Jakarta Selatan, Indonesia \\ prisild@rocketmail.com
}

Diterima: 11-08-2021 | Disetujui: 24-12-2021 | Dipublikasi: 31-01-2022

This work is licensed under a Creative Commons Attribution 4.0 International License.

\begin{abstract}
ABSTRAK
Penelitian bertujuan menjelaskan pengaruh prospek bisnis, citra, promosi, jaminan dan kepercayaan calon jamaah sebagai faktor yang mempengaruhi terhadap keberlanjutan usaha biro jasa perjalanan haji dan umrah. Populasi penelitian adalah para calon jamaah haji dan umrah yang memiliki paguyuban pada sejumlah perusahaan travel diwilayah Cilandak Timur. Sampel diambil secara acak yang dipilih dan ditentukan berdasarkan waktu pertemuan kegiatan yang sering dilaksanakan oleh paguyuban yang dibentuk calon jamaah. Pengambilan data menggunakan kuesioner yang dianalisis dengan uji validitas, reliabilitas, uji deskriptif statistik, uji hipotesis dan koefisien determinasi. Hasil penelitian menyatakan bahwa prospek bisnis, promosi dan kepercayaan berpengaruh positif signifikan terhadap keberlanjutan usaha, sedangkan jaminan tidak berpengaruh. Uji hipotesis moderasi menyatakan kepercayaan tidak memoderasi memperkuat citra dan promosi, sedangkan kepercayaan memoderasi persepsi dan jaminan yang memperkuat terhadap terhadap keberlanjutan usaha. Keterbatasan penelitian adalah sampel yang digunakan belum mampu menyimpulkan hasil penelitian secara keseluruhan dikarenakan penarikan sampel yang tidak menyeluruh pada daerah populasi karena dibatasi satu area saja. Implikasi riset berkontribusi bagi konsep pengembangan terhadap faktor yang mempengaruhi kelangsungan usaha, meningkatkan strategi bisnis, dan meningkatkan pendapatan biro jasa perjalanan haji dan umrah.
\end{abstract}

Kata Kunci:

Prospek Bisnis; Citra; Promosi; Jaminan; Kepercayaan; Kelanjutan Usaha.

\begin{abstract}
This study aims to explain the influence of business prospects, image, promotion, assurance, and trust of prospective pilgrims as factors that influence the sustainability of the Hajj and Umrah travel service bureau business. The research population is prospective hajj and umrah pilgrims who have associations with a number of travel companies in the East Cilandak region. Samples were randomly selected and determined based on the time of meeting activities often carried out by the association formed by the prospective congregation. They are collecting data using a questionnaire that was analyzed by testing the validity, reliability, descriptive statistical test, hypothesis testing, and coefficient of determination. The results of the study state that business prospects, promotions, and trust have a significant positive effect on business sustainability, while guarantees have no effect. Moderation hypothesis test states that trust does not moderate to strengthen image and promotion, while confidence moderates perceptions and strengthens assurance towards business sustainability. The limitation of the study is that the sample used has not been able to conclude the results of the study as a whole due to incomplete sampling in the population area because it is limited to one area. Nevertheless, the implications of the research are contributing to the concept of developing the factors that affect business continuity, improving business strategies, and increasing revenue for Hajj and Umrah travel agents.
\end{abstract}

Keywords:

Business Prospects; Image; Promotion; Assurance; Trust; Business Continuity 


\section{PENDAHULUAN}

Rukun Islam kelima adalah menunaikan ibadah haji ke kota suci Mekah di Arab Saudi sebagai wujud ketaatan, dan kepatuhan umat Islam menjalankan syariat agama yang telah ditentukan oleh Allah SWT. Bagi umat Islam yang mampu secara ekonomi dan finansial bercita-cita melengkapi ritual ibadahnya dengan menunaikan ibadah haji dan umrah dengan berziarah ke tempat kelahiran Nabi Muhammad SAW dimana Al Quran diturunkan. Berbagai biro jasa perjalanan haji dan umrah menawarkan perjalanan ibadah tersebut, namun permasalahan yang sering terjadi di Indonesia adalah niat suci umat muslim untuk beribadah tersebut terkadang dimanfaatkan oleh orang-orang yang tidak bertanggungjawab yang ingin mengambil keuntungan semata dan melakukan penipuan (Ningrum, 2018). Data yang diperoleh melalui Yayasan Lembaga Konsumen Indonesia (YLKI) mencatat bahwa sebanyak 22.617 pengaduan kasus penipuan umrah, terdapat tiga perusahaan yang menyelewengkan dana jamaah calon haji dan umrah yaitu: PT. First Anugerah Karya Wisata (First Travel) sebanyak 17.557 aduan, PT Assyifa Mandiri Wisata sebanyak 3.056 aduan, dan PT. Utsmaniyah Hannien Tour sebanyak 1.821 pengaduan (Reza, 2020).

Alasan masyarakat memilih untuk menggunakan biro jasa perjalanan haji dan umrah umumnya didasarkan pada faktor pribadi, sosial, dan budaya (Azyani, Sri susilawati \& Wijayanti, 2020) yang didukung dengan kepuasan dari konsumen biro perjalanan karena mendapatkan pelayanan maksimal (Faza \& Widiyanto, 2016). Penelitian ini sangat penting dilakukan karena berkontribusi besar terhadap pengaruh perkembangan industri usaha jasa perjalanan haji dan umrah yang dikelola biro perjalanan yang berdampak terhadap keberlanjutan usaha mereka di masa mendatang dengan memperhatikan aspek-aspek : persepsi konsumen terhadap prospek bisnis biro jasa perjalanan, citra dari biro jasa perjalanan haji dan umrah, promosi yang dilakukan, jaminan yang diberikan terkait dengan keberangkatan ibadah, dan timbulnya kepercayaan hasil dari pelayanan yang diberikan oleh para penyelenggara biro jasa perjalanan yang secara langsung, maupun tidak langsung akan mempengaruhi kemampulabaan mereka yang terlihat dalam arus kas. Keberlanjutan usaha dapat dilihat dari laporan arus kas yang menginformasikan kasa yang tersedia dan digunakan, sehingga dapat menjadi ukuran kinerja keuangan perusahaan (Mulyani, 2013).

Bisnis hekikatnya selalu mengalami pola perubahan dan perkembangan dari waktu ke waktu (Prihanto, 2018), terlebih dengan adanya pemanfaatan teknologi modern yang memberikan banyak kemudahan dalam praktiknya (Halbouni, Obeid \& Garbou, 2016), namun juga menimbulkan banyak penyimpangan serta kecurangan untuk diperuntukan memperoleh keuntungan semata tak terkecuali yang terjadi pada biro perjalanan. Modal utama yang diperlukan perusahaan adalah pengetahuan, keterampilan serta kemampuan yang dimiliki oleh pelaku usaha atau manajemen perlu untuk memperoleh keberlanjutan usaha (Widiastuti, 2019), keberlangsungan, keberhasilan dan kesuksesan tersebut dapat ditunjukkan dengan indikator pengungkapan pajak usaha mereka (Prihanto \& Damayanti, 2020). Lebih lanjut keberlanjutan usaha dapat dipengaruhi dari keberhasilan memelihara dan melayani pelanggan dengan baik yang dan mendapat kepuasan sehingga meningkatkan loyalitas pelanggan (Putri, 
Suharyono \& Fanani, 2015). Adanya promosi, kepercayaan dan kesadaran merek juga memberikan pengaruh dalam memilih produk menabung untuk ibadah haji (Tajudin \& Mulazid, 2017; Santosa, Mahendra \& Haryanto, 2019), sehingga situasi ini akan membangun keunggulan kompetitif untuk memenangkan persaingan dan berkelanjutan usaha (Dalimunthe, 2017) dalam biro jasa perjalanan haji dan umrah. Berdasar fenomena tersebut penelitian ini bertujuan untuk menjelaskan berbagai faktor yang diprediksi berpengaruh terhadap kelangsungan usaha biro perjalanan haji dan umrah melalui : persepsi prospek bisnis, citra perusahaan, promosi yang dilakukan, jaminan serta kepercayaan para konsumen pengguna biro perjalanan haji dan umrah. Riset berimplikasi dalam merekomendasikan literasi bagi biro jasa perjalanan haji dan umrah dalam meningkatkan keberlanjutan usaha yang meliputi strategi bisnis yang meningkatkan pendapatan usaha.

\section{Teori Pemangku Kepentingan}

Teori pemangku kepentingan digunakan karena menyatakan tentang kaitan kelompok atau individu yang saling mempengaruhi atau dipengaruhi untuk mencapai keinginan para pemangku kepentingan (Hong and Andersen, 2011; Razafindrambinina \& Sabran, 2014) seperti halnya para jamaah haji dan umrah dalam risret ini. Selain itu serta menggambarkan tanggungjawab yang harus dilakukan terhadap kepada pihak dan siapa saja baik internal maupun eksternal yang berkepentingan pada organisasi dan menimbulkan kemanfaatan yaitu dapat meningkatkan citra maupun reputasi perusahaan yang berdampak pada produktivitas dan kinerja keuangan perusahaan yang positif (Crisostomo, Freire \& Vasconcellos, 2011). Teori pemangku kepentingan memiliki kelemahan dimana fokus teori hanya tertuju pada pola serta cara-cara yang digunakan perusahaan untuk mengatur pemangku, bertanggung jawab dan memenuhi tujuan perusahaan didasarkan pada kebutuhan masyarakat secara seimbang menurut kepentingan tersebut (Quazi \& Richardson, 2012). Untuk itu dalam pengelolaan manajemen perusahaan seringkali terjadi perilaku moral hazard yang menyangkut ketidakjujuran, etika, moral dan perilaku untuk memenuhi keinginan pelaku dari para pemilik travel akibat konflik kepentingan, lebih lanjut perilaku oportunistik dapat dilakukan untuk mendapatkan keinginan pribadi atau kelompok (Damayanty \& Murwaningsari, 2020). Pendapat ini ternyata bertolak belakang dengan pernyataan sebelumnya (Wicks \& Harrison, 2017) yang menyatakan bahwa perusahaan hadir dengan tujuan untuk melayani dan memajukan manusia yang dilakukan secara terfokus. Perusahaan seharusnya sebagai organisasi yang dipercaya oleh publik merupakan bagian dari masyarakat yang bermitra, perusahaan juga berhutang pada mereka pada tempat mereka beroperasi, dan mereka juga harus berperilaku dengan rasa tanggung jawab yang lebih besar bukan sekadar melakukan tindakan yang menguntungkan saja, dengan konsekuensi tidak melanggar hukum yang berlaku (Kourula \& Delalieux, 2016).

\section{Tata kelola}

Prinsip pengelolaan yang baik akan membantu organisasi dalam meningkatkan integritas dan memperoleh kepercayaan dari masyarakat (Zulkifli, Shokiyah \& Mohd Serjana, 2014), karena pada 
hakekatnya konsep tata kelola yang baik sarat dengan nilai yang merekomendasikan pada perilaku administratif yang ideal serta menolak perilaku yang tidak etis dan tidak bertentangan dengan perilaku menyimpang yang melibatkan kepemimpinan dalam organisasi (Umar, 2016; Prihanto \& Gunawan, 2020). Kehadiran tata kelola perusahaan yang baik (GCG) sangat diperlukan oleh sebuah organisasi, karena dengan sistem tata kelola yang baik yang dapat membantu membangun kepercayaan pemegang saham dan memastikan bahwa semua pemangku kepentingan diperlakukan sama (Mahrani \& Soewarno, 2018) serta memberikan perlindungan yang efektif kepada pemangku kepentingan yang memastikan bahwa manajemen bertindak tidak semata untuk kepentingan perusahaan saja (Mahrani \& Soewarno, 2018). Dasar penggunaan teori tata kelola dalam riset adalah dapat mencegah penyimpangan atau mengurangi manajemen laba, karena pengawasan tersebut menjadi insentif bagi manajemen sebagai agen untuk bertindak sebaik mungkin demi kepentingan prinsipal yang dapat dipertanggungjawabkan sesuai tugas mereka dengan benar (Uwuigbe, Sunday \& Oyeniyi, 2014).

\section{Persepsi prospek bisnis terhadap keberlanjutan usaha}

Persepsi terhadap prospek bisnis perusahaan dari pelanggan sangat penting dalam menentukan jumlah investasi yang ditanamkan dan menentukan arus modal serta arus kas perusahaan, sehingga bisnis dapat dilakukan dan didukung dengan perencanaan dengan baik dan menghasilkan kesinambungan disertai dengan analisis yang akurat (Cervone, 2017), yaitu dimana kegiatan-kegiatan proyek yang dilakukan memberikan prospek terhadap kebutuhan masyarakat (Couldry \& Powell, 2014). Besar dan kecilnya perusahaan menjadi persepsi penilaian bagi konsumen dalam memilih untuk menggunakan jasa maupun berinvestasi dipengaruhi : jenis, tempat organisasi menurut persepsi pribadi konsumen (Zainal et al., 2017; Azyani, Sri susilawati \& Wijayanti, 2020), persepsi tersebut dalam jangka pendek maupun panjang menentukan keberlanjutan suatu bisnis, terlebih pengelolaan biro perjalanan haji dan umrah dilakukan dengan akuntansi yang baik dan prinsip Islam akan lebih menuai kesuksesan (Umar, Shamsudin \& Mohamed, 2017). Semakin baik persepsi para konsumen terhadap biro perjalanan haji dan umrah, maka akan berpengaruh terhadap keberlanjutan usahanya dimasa depan dengan meningkatkan nilai ekonomi biro perjalanan tersebut, sehingga hipotesis penelitian satu (H1) dikemukakan :

H1: Persepsi baik publik tentang prospek bisnis berpengaruh positif terhadap keberlanjutan usaha.

\section{Kepercayaan memoderasi persepsi publik terhadap keberlanjutan usaha}

Persepsi konsumen tentang bisnis yang dilakukan oleh perusahaan memberikan harapan yang positif dalam meningkatkan kinerja bisnis travel haji dan umrah (Crisostomo, Freire \& Vasconcellos, 2011; Azyani, Sri susilawati \& Wijayanti, 2020), dan akan lebih baik lagi apabila didukung dengan kepercayaan (Tajudin \& Mulazid, 2017; Santosa, Mahendra \& Haryanto, 2019). Prospek bisnis akan lebih baik apabila disertai dengan adanya kepercayaan dari pihak lain bukan hanya untuk meningkatkan relasi, namun lebih jauh dapat meningkatkan nilai sosio-ekonomis yang belum tentu didapatkan dari masyarakat (Saikouk et al., 2021), kepercayaan juga digambarkan melalui perilaku publik yang positif 
menyebabkan lancarnya bisnis (McCarter, Mahoney \& Northcraft, 2011). Kepercayaan yang dipelihara dengan baik akan melahirkan minat dari mitra untuk melakukan kerjasama yang dapat meminimalisasi ketidakpastian (Villena, Revilla \& Choi, 2011) yang terjadi dalam bisnis, dengan adanya kepercayaan menjadi faktor yang memoderasi dengan memperkuat persepsi publik terhadap keberhasilan dalam kelangsungan bisnis, untuk itu hipotesis penelitian dikemukakan:

H1a: Kepercayaan publik memoderasi dengan memperkuat pengaruh prospek bisnis terhadap keberlanjutan usaha

\section{Citra dan keberlanjutan usaha}

Citra perusahaan merupakan faktor yang tidak dapat diabaikan dalam membina hubungan bisnis, citra yang baik menimbulkan kepercayaan dan sanggup untuk membuat persepsi konsumen menjadi positif untuk bermitra dan membina kerjasama yang menguntungkan terhadap bisnis (Blombäck \& Scandelius, 2013). Demikian pula kinerja yang terkait dengan tanggung jawab sosial dan lingkungan perusahaan merupakan indeks penting dan mampu meningkatkan reputasi atau citra perusahaan (Crisostomo, Freire \& Vasconcellos, 2011). Moral perusahaan menjadi hal penting yang dapat menghancurkan atau membangun perusahaan, selain wujud tanggung jawab perusahaan pada masyarakat yang kemudian menghasilkan pujian atas keberhasilan pengelolaan perusahaan (Castrogonz \& Fern, 2019), selanjutnya dapat menyelamatkan bisnis perusahaan. Citra positif perusahaan akan mendorong tumbuh dan berkembang usaha yang dirintis, untuk itu citra yang semakin baik perusahaan akan memberikan jaminan dalam keberlanjutan usaha yang mereka bangun di masa mendatang, sehingga hipotesis penelitian dua (H2) dapat dikemukakan sebagai berikut:

$\mathrm{H} 2$ : Citra yang baik dari perusahaan berpengaruh positif terhadap keberlanjutan usaha

\section{Kepercayaan memoderasi citra terhadap keberlanjutan usaha}

Citra publik yang baik mendatangkan kepercayaan terhadap perusahaan dan sangat penting karena menyangkut opini masyarakat tentang pandangan perusahaan yang menjadi partnernya dalam mencapai tujuannya. Citra yang baik tersebut akan mendatangkan pandangan yang positif terhadap bisnis perusahaan dan kemudian mendatangkan kepercayaan dari konsumen untuk selalu menggunakan barang dan jasa yang merupakan produk dari perusahaan (Mardiana \& Rahmidani, 2020). Sementara itu minat untuk membeli atau menggunakan jasa di antaranya juga dapat dipengaruhi oleh citra perusahaan yang diperkuat dengan dukungan kepercayaan dan loyalitas dari konsumen terhadap perusahaan dalam menggunakan barang atau jasanya (Ariszani, Suharyono \& Kumadji, 2015), kepercayaan dapat terjadi karena akreditasi atau citra yang baik dimiliki organisasi (Damayanti, Fathorrahman \& Pradiani, 2020). Untuk itu citra baik dari perusahaan mampu mendatangkan kepercayaan publik dengan memoderasi yang memperkuat keinginan untuk bermitra sehingga keberlangsungan bisnis travel dapat diperoleh, oleh karenanya hipotesis penelitian dapat dikemukakan sebagai berikut: 
H2a: Kepercayaan memoderasi yang memperkuat pengaruh citra baik perusahaan terhadap keberlanjutan usaha

\section{Promosi terhadap keberlanjutan usaha}

Promosi merupakan media efektif dalam memperkenalkan dan menyebarluaskan produk yang dimiliki perusahaan terhadap publik, pemasar dan pengecer yang sering kali menggunakan promosi dalam penjualannya dapat mempengaruhi pembelian konsumen dan didasari keputusan merek (Tajudin \& Mulazid, 2017; Santosa, Mahendra \& Haryanto, 2019). Promosi yang dilakukan menggunakan uang meliputi diskon atau kupon, terkadang bisa menjadi sangat efektif dalam menghasilkan pengaruh jangka pendek pada penjualan (Tajudin \& Mulazid, 2017; Santosa, Mahendra \& Haryanto, 2019). Promosi yang efektif adalah mampu mendukung perilaku konsumen dalam memperoleh tujuan memilih membelanjakan uangnya (Baker and Wakefield, 2012; Oliver, Florack \& Goritz, 2013), semakin banyaknya perputaran barang dan jasa pada perusahaan maka keberlanjutan usaha akan semakin terjamin. Untuk itu semakin efektif promosi yang dilakukan perusahaan, akan mengerakkan konsumen untuk menggunakan barang dan jasa yang ditawarkan perusahaan, sehingga semakin efektif konsumen yang menggunakan biro jasa perjalanan haji dan umrah mendukung keberlanjutan usahanya, untuk itu hipotesis penelitian tiga (H3) dikemukakan sebagai berikut:

H3: Promosi yang efektif akan berpengaruh positif pada keberlanjutan usaha

\section{Kepercayaan memoderasi promosi terhadap keberlanjutan usaha}

Kepercayaan konsumen kepada biro perjalanan terjadi dikarenakan penilaian yang positif dan baik terhadap suatu produk (Damayanti, Fathorrahman \& Pradiani, 2020), sehingga kepercayaan yang timbul dari konsumen dapat mendukung promosi yang dilakukan menjadi efektif dalam memperkenalkan produk yang akan dijual kepada konsumen. Promosi yang baik pada hakekatnya mendatangkan kepercayaan yang kuat kepada konsumen untuk membeli atau menggunakan barang dan jasa yang ditawarkan (Putra, 2016; Subardi, 2018). Promosi yang dilakukan dengan baik dan disertai dengan kenyataan, akan menimbulkan kepercayaan bagi para konsumen dalam menggunakan jasa, atau sebaliknya dengan kepercayaan yang sudah tertanam dihati publik sebelumnya terhadap produk akan lebih memperkuat promosi dalam meningkatkan jumlah konsumen pengguna biro perjalanan sehingga keberlanjutan usaha dapat diperoleh. Untuk itu promosi yang didukung dengan kepercayaan dari publik mampu menghasilkan niat untuk menggunakan produk yang selanjutnya mempengaruhi keberlangsungan bisnis perusahaan, untuk itu hipotesis penelitian dikemukakan sebagai berikut:

H3a: Kepercayaan publik dapat memoderasi dengan memperkuat pengaruh promosi yang efektif terhadap keberlanjutan usaha

\section{Jaminan pengelolaan dan keberlanjutan usaha}

Jaminan merupakan sesuatu tindakan yang diberikan oleh pihak pertama kepada kedua terkait untuk memberikan keyakinan kepada pihak kedua, dalam hal ini untuk menggunakan jasa yang berhubungan sesuatu yang dijanjikan biro jasa perjalanan yaitu keberangkatan haji atau umrah. 
Penelitian sebelumnya menyatakan bahwa jaminan memberikan daya tarik dan berpengaruh positif terhadap publik untuk berinvestasi (Saputri \& Purbawangsa, 2016; Hasan \& Dana, 2018). Jaminan juga mampu memberikan kekuatan membangun pasar yang menyebabkan bisnis menjadi lebih baik dengan kepuasan konsumen (Faza \& Widiyanto, 2016). Semakin tinggi dan baiknya jaminan yang akan diperoleh dapat memberikan rasa aman kepada konsumen terhadap keputusan pemakaian suatu produk, serta memberikan keyakinan pada konsumen dalam menggunakan produk tersebut yang berakibat meningkatkan kinerja yang mendorong keberlangsungan bisnis biro perjalanan, untuk itu hipotesis empat (H4) dikemukakan sebagai berikut:

H4: Jaminan yang semakin baik diberikan berpengaruh positif terhadap keberlanjutan usaha

\section{Kepercayaan memoderasi jaminan terhadap keberlanjutan usaha}

Jaminan yang dimaksud pada penelitian ini merupakan sesuatu yang menurut publik secara nilai akuntansi dapat diandalkan seperti: uang, aktiva, ataupun progres lain yang dijanjikan untuk meyakinkan dan menimbulkan reaksi konsumen untuk menggunakan produk perusahaan secara pribadi (Azyani, Sri susilawati \& Wijayanti, 2020). Kepercayaan akan timbul manakala perusahaan mampu meyakinkan jaminan yang diberikan pada konsumen layak terhadap bisnis perusahaan, oleh karenanya jaminan rasa aman yang diberikan oleh perusahaan berakibat timbulnya kepercayaan dari para konsumen (Setyawan \& Japarianto, 2014). Jaminan terhadap kualitas jasa memberikan pengaruh terhadap minat menggunakan jasa dengan dilandasi kepercayaan yang menghubungkan di antara kedua variabel tersebut (Hakim \& Idris, 2017), Adanya jaminan yang dianggap memberi rasa aman oleh konsumen kemudian menimbulkan kepercayaan dan mempengaruhi minat untuk memutuskan untuk menggunakan barang dan jasa, sehingga meningkatkan profitabilitas yang mendorong keberlanjutan usaha untuk itu hipotesis penelitian dikemukakan sebagai berikut:

H4a: Kepercayaan dapat memoderasi dengan memperkuat pengaruh jaminan yang diberikan terhadap keberlanjutan usaha

\section{Kepercayaan dan keberlanjutan usaha}

Kepercayaan merupakan modal utama dalam membangun mitra bisnis, dimana kepercayaan dari pihak lain pada perusahaan yang lebih kuat akan mempengaruhi perilaku para konsumen dalam memandang sebagai kebutuhan atau syarat utama yang menjamin keberlanjutan dalam bisnis (Silvola \& Vinnari, 2021), sementara itu komitmen menjaga kepercayaan yang dibangun dengan baik akan membangun hubungan bisnis yang sukses (Akrout, 2019). Selain itu kepercayaan juga mampu meningkatkan nilai kemitraan dalam bentuk tambahan relasi bisnis lain yang menguntungkan, terkadang hal tersebut tidak dapat diperoleh dari hubungan secara ekonomi dan sosio yang dibina (Saikouk et al., 2021). Dengan demikian kepercayaan yang dipelihara dan dibangun dengan baik berpengaruh terhadap keberlanjutan usaha yang membangun bisnis yang berkelanjutan, sehingga hipotesis penelitian lima (H5) dapat dikemukakan sebagai berikut: 
H5: Kepercayaan yang komitmen dipelihara dengan baik berpengaruh positif terhadap keberlanjutan usaha.

\section{METODE RISET}

\section{Desain penelitian}

Penelitian ini dilakukan dengan menggunakan pendekatan asosiatif kausal salah satu jenis penelitian kuantitatif, dimana peneliti menguji beberapa variabel penyebab kelangsungan bisnis dengan sejumlah variabel sebagai pemrediksi. Variabel pemrediksi terdiri dari variabel bebas yang memprediksi variabel terikat yang merupakan model utama penelitian, sementara variabel moderasi berfungsi sebagai variabel yang memperkuat atau memperlemah pengaruh variabel bebas terhadap variabel terikat disebut dengan model yang dimodifikasi. Populasi pada penelitian ini merupakan masyarakat muslim wilayah Cilandak Timur Jakarta Selatan yang menjadi sudah atau calon jamaah haji dan umrah yang akan menunaikan ibadah tersebut yang ditetapkan sebagai sampel penelitian. Teknik pengambilan sampel menggunakan pendekatan klaster karena terdiri dari beberapa perkumpulan yang kemudian diambil secara acak, dilakukan karena sampel (jamaah dan calon) memiliki pada saat dilakukan pengambilan data responden banyak sekali yang hadir dengan waktu yang tidak bersamaan. Selain itu, peneliti juga melakukan pengambilan sampel dengan ikut serta pada beberapa pertemuan yang diadakan oleh travel pengelola jasa umrah dan haji. Pengumpulan data primer digunakan kuesioner yang merupakan persepsi dari responden terhadap penilaian perusahaan biro jasa yang mengadakan urusan haji dan umrah. Penelitian dilakukan selama bulan Januari sampai dengan Mei 2019 dengan perolehan sampel sebesar 200 calon jamaah, dan mereka yang telah menunaikan ibadah haji dan umrah. Analisis data menggunakan alat bantu SPSS dengan uji validitas dan reliabilitas instrumen, statistik deskriptif serta uji hipotesis dengan uji t, regresi berganda linear, regresi menggunakan variabel moderasi dengan menyertakan kepercayaan sebagai variabel independen yang dilakukan dengan Moderated Regression Analysis (MRA) yaitu aplikasi khusus regresi berganda linear dimana dalam persamaan regresinya mengandung unsur interaksi (perkalian dua atau lebih variabel independen), dan koefisien determinasi dilakukan untuk melihat kelayakan model penelitian. Untuk memperjelas hubungan antar variabel penelitian dapat digambarkan dalam kerangka model dapat dilihat pada gambar 1.

\section{Pengukuran}

Pengukuran variabel penelitian ini menggunakan referensi penelitian sebelumnya yang dilakukan dari eksplorasi peneliti dengan menggunakan data ordinal, dan skala interval yang berbentuk persepsi dari responden (calon jamaah dan jamaah) yang menggunakan penskalaan menurut Likert yang dimodifikasi dengan tidak menggunakan jawaban netral sebagai berikut: 1 (sangat tidak setuju), 2 (tidak setuju), 3 (kurang setuju), 4 (setuju), dan 5 (setuju sekali). Masing masing variabel kemudian diukur sebagai berikut: Prospek bisnis diukur menggunakan dimensi: diri sendiri, perubahan yang terjadi, 
persepsi konsumen (Hendro, 2011). Citra perusahaan diukur dengan menggunakan dimensi : brand personality, brand attitude, brand benefit dan brand competence (Roslina, 2010). Promosi diukur dengan menggunakan : periklanan, promosi penjualan, komunikasi dengan publik (Phillip \& Keller, 2012). Jaminan diukur dengan menggunakan dimensi : pengetahuan dan kesopanan (Fitzsimmons \& Mona, 2011), sedangkan kepercayaan mengadopsi dari penelitian sebelumnya (Andini, Suharyono \& Sunarti, 2014) yaitu dimensi : benevolence, competence dan honesty. Variabel dependen keberlanjutan usaha diukur menggunakan dimensi : modal, aset, manajemen, dan likuiditas (Arens \& Loebbecke, 1996)

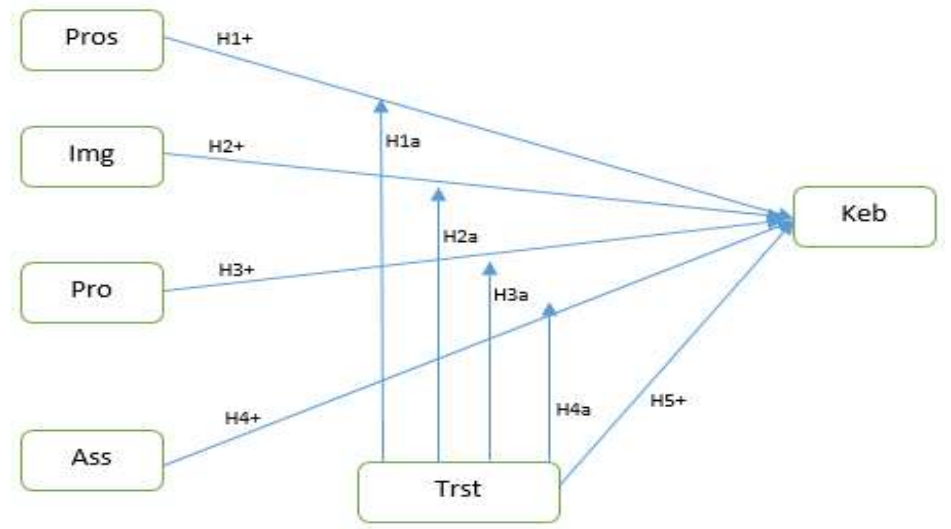

Gambar 1. Kerangka model penelitian

\section{HASIL PENELITIAN DAN PEMBAHASAN}

\section{Hasil penelitian}

Hasil pengolahan data dengan menggunakan SPSS menghasilkan output awal terhadap instrumen penelitian yaitu uji deskriptif, validitas, dan reliabilitas yang tergambar dengan jumlah observasi terhadap sejumlah jamaah haji dan umrah yang sudah melaksanakan atau yang sedang dalam masa tunggu dan diperoleh dalam periode penelitian pada tabel 1 berikut :

Tabel 1. Deskripsi Statistik dan Uji Instrumen Data

\begin{tabular}{|c|c|c|c|c|c|c|}
\hline Model & Min & Max & Mean & Std. Dev & Validity & Reliability \\
\hline Pros & 11,00 & 30,00 & 20,1400 & 3,95965 & $0.519-0.732(\mathrm{~V})$ & $0.787(\mathrm{R})$ \\
\hline Img & 14,00 & 30,00 & 22,0350 & 3,85462 & $0.637-0.774(\mathrm{~V})$ & $0.733(\mathrm{R})$ \\
\hline Pro & 15,00 & 30,00 & 22,4050 & 3,62999 & $0.602-0.735(\mathrm{~V})$ & $0.795(\mathrm{R})$ \\
\hline Ass & 10,00 & 20,00 & 14,3100 & 2,61881 & $0.701-0.730(\mathrm{~V})$ & $0.752(\mathrm{R})$ \\
\hline Trst & 13,00 & 30,00 & 20,9050 & 3,69244 & $0.619-0.714(\mathrm{~V})$ & $0.696(\mathrm{R})$ \\
\hline Keb & 16,00 & 40,00 & 26,8650 & 4,95678 & $0.585-0.731(\mathrm{~V})$ & $0.760(\mathrm{R})$ \\
\hline \multicolumn{7}{|c|}{$\mathrm{N}=200, \mathrm{r}$ tabel $: 0.116($ dengan $\mathrm{n} 200)$} \\
\hline \multicolumn{7}{|c|}{$\begin{array}{l}\text { Pros: prospek bisnis, Img: citra, Pro: Promosi, Ass: kepercayaan, Trst : kepercayaan, Keb } \\
\text { keberlanjutan usaha } \\
(\mathrm{V})=\text { valid }(\mathrm{R})=\text { reliabel }\end{array}$} \\
\hline
\end{tabular}

Hasil pengujian menunjukan bahwa seluruh variabel yang digunakan dalam penelitian berdistribusi normal dengan ditunjukan nilai mean yang lebih besar dari standar deviasi, dengan nilai minimal dan maksimal terbentang cukup jauh yang artinya data tersebut memiliki kolom data yang cukup luas atau lebar. Sedangkan pada uji validitas dan reliabilitas dihasilkan bahwa seluruh variabel 
yang digunakan dalam penelitian dinyatakan layak, artinya seluruh instrumen yang digunakan melewati uji validitas dan reliabilitas dan dapat digunakan pada pengujian selanjutnya. Persamaan regresi dengan menggunakan model utama dan menggunakan variabel moderasi dapat ditampilkan sebagai berikut :

Keb1 $=$ 1.341 $\square+$ 0.404Pros + 0.189Img + 0.032Pro + 0.457Ass + 0.544Trst + e

Keb2 $=$-3.612 $\square+$ 0.603Pros $*$ Trst + 0.032Img*Trst -0.053 Pro*Trst + 0.551Ass $*$ Trst + e

Persamaan diperoleh dari hasil pengujian hipotesis dengan menggunakan model utama (regresi variabel bebas dan terikat), dan menggunakan model yang dimodifikasi yang juga menyertakan regresi variabel moderating dapat ditampilkan pada tabel 2 berikut:

Tabel 2. Uji hipotesis utama dan modifikasi

\begin{tabular}{|c|c|c|c|c|c|c|c|c|}
\hline \multirow[b]{2}{*}{ Model } & \multicolumn{4}{|c|}{ Model utama } & \multicolumn{4}{|c|}{ Model modifikasi } \\
\hline & $\beta$ & $\mathrm{t}$ & Sig & Ket & $\beta$ & $\mathrm{t}$ & sig & Ket \\
\hline Pros & 0.404 & 1.451 & $0,07 *$ & Diterima & 0.603 & 12.316 & $0,00 * * * *$ & Diterima \\
\hline Img & 0.189 & 8.991 & $0.00 * * * *$ & Diterima & 0.032 & 0.517 & 0,30 & Ditolak \\
\hline Pro & 0.032 & 2.469 & $0.00 * * * *$ & Diterima & -0.053 & -0.666 & 0,25 & Ditolak \\
\hline Ass & 0.457 & 0.313 & 0.37 & Ditolak & 0.551 & 6.193 & $0,00 * * * *$ & Diterima \\
\hline Trst (mod) & 0.544 & 9.465 & $0.00 * * * *$ & Diterima & - & - & - & - \\
\hline$\square:$ & 1.341 & & -3.612 & & & \\
\hline Error : & \multirow{2}{*}{\multicolumn{3}{|c|}{$\begin{array}{l}0.924 \\
0.707\end{array}$}} & & \multicolumn{4}{|c|}{2.018} \\
\hline Adj. $R^{2}$ : & & & & & \multicolumn{4}{|c|}{0.906} \\
\hline $\mathrm{F} \quad:$ & \multicolumn{4}{|c|}{$1210.63 * * * *$} & \multicolumn{4}{|c|}{$321.498 * * * *$} \\
\hline
\end{tabular}

Note sig : $*=0.10, * *=0.05, * * *=0.01, * * * *=0.000$

Keb : dependen variabel

Sumber: Data diolah, 2021

Pengujian hipotesis penelitian ini menggunakan model utama dan modifikasi dimana dalam model tersebut variabel kepercayaan yang berfungsi ganda, yaitu sebagai variabel moderating dan juga sebagai variabel independen (Quasi Moderator). Hasil pengujian hipotesis tidak semua variabel diterima yaitu pada saat diuji menggunakan uji hipotesis utama variabel jaminan (H4) tidak ditolak sedangkan H1, H2, H3 dan H5 diterima. Sedangkan pada pengujian hipotesis model modifikasi menyatakan bahwa citra dan promosi ( $\mathrm{H} 2 \mathrm{a}$ dan $\mathrm{H} 3 \mathrm{a})$ ditolak dikarenakan kepercayaan tidak dapat memoderasi yang memperkuat terhadap keberlanjutan usaha, dan justru sebaliknya memperlemah hubungan kedua variabel tersebut. Koefisien determinasi yang diperoleh sebesar 0.70 pada model utama dan 0.90 pada model modifikasi menandakan bahwa pemilihan variabel yang digunakan dalam penelitian sangat layak memenuhi ketentuan goodness of fit, terutama setelah adanya kepercayaan sebagai moderasi yang meningkatkan koefisien tersebut sebesar 0.20 membuat komposisi model dalam penelitian ini sangat baik. Begitu pula dengan pengujian F statistik yang menunjukan komposisi model dari data yang diperoleh dengan tingkat signifikansi sebesar 0.00 , menunjukkan karakteristik data berdistribusi normal.

\section{Pembahasan}

\section{Model utama}

Pembahasan hasil uji hipotesis model utama menggunakan hasil regresi langsung tanpa menggunakan peran variabel moderating dilakukan dengan melewati prosedur dengan asumsi rule of 
thumb menyatakan bahwa persepsi konsumen tentang prospek bisnis berpengaruh positif terhadap keberlanjutan usaha biro perjalanan haji dan umrah, sehingga $\mathrm{H} 1$ diterima. Hasil didukung dengan penelitian sebelumnya bahwa persepsi pribadi jamaah menentukan dalam memilih biro perjalanan haji dan umrah (Zainal et al., 2017; Azyani, Sri susilawati \& Wijayanti, 2020) yang tentunya didukung dengan perencanaan yang baik (Cervone, 2017) yang berprospek terhadap pelayanan kebutuhan masyarakat (Couldry \& Powell, 2014) terutama yang berkaitan pelayanan pada jamaah haji dan umrah. Prospek bisnis perusahaan merupakan hasil akumulasi persepsi dan pandangan dari pihak konsumen yang sangat penting karena terkait dengan kemampuan pengelolaan biro jasa perjalanan haji dan umrah, terlebih jika ditambah dengan menggunakan akuntansi yang baik dan menerapkan prinsip Islami (Umar, Shamsudin \& Mohamed, 2017). Efek dari pilihan jamaah tersebut memberikan peluang biro perjalanan untuk meningkatkan pendapatan mereka semakin tinggi karena perputaran arus kas yang tinggi dan kinerja positif yang baik (Crisostomo, Freire \& Vasconcellos, 2011; Mulyani, 2013).

Hasil uji H2 menyatakan citra baik perusahaan berpengaruh secara positif terhadap sikap konsumen yang memilih biro perjalanan yang mereka gunakan, dengan demikian H2 penelitian diterima. Hasil penelitian didukung penelitian sebelumnya (Crisostomo, Freire \& Vasconcellos, 2011; Blombäck \& Scandelius, 2013; Castro-gonz \& Fern, 2019), bahwa dengan citra perusahaan yang baik dan positif sudah berfungsi sebagai promosi yang efektif yang membantu untuk menarik minat konsumen dalam memilih produk, dikarenakan tanpa mengeluarkan biaya besar melalui slogan-slogan dalam iklan media maka citra sekaligus promosi yang efektif kepada masyarakat (Baker \& Wakefield, 2012; Oliver, Florack \& Goritz, 2013). Berdasarkan pengamatan biro perjalanan haji dan umrah di Indonesia lebih banyak dipilih berdasarkan metode ketok tular, dimana satu orang jamaah dan calon jamaah yang telah merasakan pelayanan yang diberikan oleh biro tersebut kemudian memberikan rekomendasinya kepada pihak lain untuk menggunakan jasa biro perjalan tersebut yang disebut juga sebagai customer loyalty. Fenomena tersebut dapat menjadi strategi yang perlu dilakukan dan menjadi tantangan untuk memperoleh tingkat pendapatan yang mendukung keberlanjutan usaha.

Uji hipotesis tiga menyatakan bahwa promosi berpengaruh positif signifikan terhadap keberlanjutan usaha sehingga $\mathrm{H} 3$ diterima. Hasil penelitian didukung dengan penelitian sebelumnya yang menyatakan bahwa selain merek yang baik, ternama dan terkenal, promosi juga dilakukan dengan memberikan potongan harga, kupon menarik minat konsumen membeli (Tajudin \& Mulazid, 2017; Santosa, Mahendra \& Haryanto, 2019) karena dianggap menguntungkan dan mempengaruhi keberlanjutan usaha karena arus kas yang positif dan menentukan kinerja dari perusahaan yang positif (Mulyani, 2013). Lebih lanjut promosi yang efektif adalah mampu mendukung perilaku konsumen dalam memperoleh tujuan mereka dalam berbelanja atau membeli (Baker \& Wakefield, 2012; Oliver, Florack \& Goritz, 2013), lalu bertanggung jawab dan memenuhi tujuan perusahaan didasarkan pada kebutuhan masyarakat (jamaah) secara seimbang menurut kepentingan tersebut (Quazi and Richardson, 2012). 
Kegagalan biro perjalanan adalah manakala tidak mampu meyakinkan para jamaah haji dan umrah untuk dapat berangkat ibadah pada waktunya, faktor ini membuat jamaah menjadi ragu terhadap ketercapaian tujuan mereka, sehingga banyak konsumen sangat selektif dalam memilih biro perjalanan karena jaminan yang diberikan tidak meyakinkan, sehingga faktor jaminan tidak berpengaruh terhadap keberlanjutan usaha dan H4 ditolak. Hasil tidak mendukung penelitian sebelumnya (Faza \& Widiyanto, 2016; Saputri \& Purbawangsa, 2016; Hasan \& Dana, 2018) dimana jaminan yang diberikan seharusnya menjadi daya tarik konsumen untuk membeli atau berinvestasi. Jaminan sebagai strategi dalam bisnis diwujudkan dengan kemampuan biro perjalanan untuk menjamin para calon jamaahnya untuk dapat berangkat beribadah ke kota Mekah yang mendorong para jamaah untuk menggunakan jasa biro perjalanan yang meningkatkan arus kas. Namun berdasarkan fenomena yang ada banyak biro perjalanan yang ingkar janji kepada jamaah dan melakukan kecurangan dengan tindakan moral hazard, dan penipuan yang tidak bertanggungjawab dengan benar (Uwuigbe, Sunday \& Oyeniyi, 2014) menyebabkan permasalahan bagi para jamaah yang gagal dalam berangkat menunaikan ibadah (Reza, 2020), sehingga kepentingan dan tujuan jamaah tidak tercapai (Hong \& Andersen, 2011; Razafindrambinina and Sabran, 2014).

Kepercayaan sebagai bagian penting dimulainya bisnis berpengaruh terhadap keberlanjutan usaha maka uji hipotesis H5 penelitian diterima, dan didukung penelitian sebelumnya (Damayanti, Fathorrahman \& Pradiani, 2020) yang menyatakan bahwa penilaian positif terhadap produk meningkatkan kepercayaan menggunakan produk untuk memilih biro perjalanan haji dan umrah (Putra, 2016; Subardi, 2018) yang berpengaruh pada kinerja keuangan yang menentukan keberlanjutan usaha (Crisostomo, Freire \& Vasconcellos, 2011; Mulyani, 2013; Dalimunthe, 2017; Widiastuti, 2019). Kepercayaan merupakan faktor pembuka bagi keberlanjutan bisnis, karena kepercayaan merupakan sikap yang positif dan memberikan peluang bekerja sama yang diharapkan tertanam pada diri jamaah atau konsumen untuk menggunakan produk yang ditawarkan dan menjadi kunci keberhasilan bisnis (Akrout, 2019; Saikouk et al., 2021; Silvola \& Vinnari, 2021).

Hasil uji hipotesis model utama menyatakan bahwa keberlanjutan usaha biro perjalanan haji dan umrah dapat didukung dan ditentukan dari faktor persepsi prospek bisnis, citra, promosi dan kepercayaan konsumen yang seharusnya memudahkan biro perjalanan untuk meningkatkan arus kas penerimaan dana dan memperoleh modal usaha perusahaan yang menjadi salah satu jaminan keberlanjutan usaha dimasa mendatang secara langsung maupun tidak langsung. Namun Permasalahan yang sering dialami penyelenggara biro perjalanan adalah pengelolaan yang didalamnya terdapat konflik kepentingan dimana keuangan perusahaan seringkali digunakan untuk kepentingan pribadi seperti yang dialami : PT. First Anugerah Karya Wisata (First Travel), PT Assyifa Mandiri Wisata, PT Utsmaniyah Hannien Tour (Reza, 2020). Akibat dari peristiwa tersebut merugikan para pemangku kepentingan jamaah (Kourula \& Delalieux, 2016; Wicks \& Harrison, 2017) dengan batalnya ibadah haji dan umrah mereka. Ketertarikan masyarakat dalam menggunakan biro perjalanan dikarenakan persepsi yang positif, promosi yang gencar dilakukan, citra positif yang selama ini dibangun serta 
kepercayaan akan biro perjalanan yang profesional dalam melayani jamaah dengan memberangkatkan mereka yang dibuktikan dengan tata kelola yang yang baik (Zulkifli, Shokiyah \& Mohd Serjana, 2014) serta mengakomodir kepentingan para pemangku kepentingan (Mahrani \& Soewarno, 2018).

\section{Model modifikasi}

Uji hipotesis model modifikasi dengan menggunakan kepercayaan sebagai variabel moderasi telah menghasilkan beberapa hipotesis yang diterima, di antaranya meliputi persepsi prospek bisnis melalui konsumen terhadap keberlanjutan usaha biro perjalanan yang dimoderasi da diperkuat oleh kepercayaan yang hasilnya adalah H1a dapat diterima. Hasil penelitian ini didukung dengan penelitian sebelumnya (McCarter, Mahoney \& Northcraft, 2011; Villena, Revilla \& Choi, 2011; Saikouk et al., 2021) yang menyatakan bahwa adanya prospek bisnis perusahaan yang baik dimasa mendatang didukung dengan kepercayaan dari para konsumen untuk menggunakan dan memilih jasa yang ditawarkan biro jasa perjalanan haji dan umrah. Prospek bisnis yang baik didukung dengan kepercayaan memberikan penguatan dan keyakinan bagi jamaah dalam memilih biro perjalanan karena didasarkan kinerja yang baik (Crisostomo, Freire \& Vasconcellos, 2011; Mulyani, 2013) dan keyakinan untuk tercapainya tujuan para pemangku kepentingan untuk berangkat ibadah ke Tanah Suci (Mahrani \& Soewarno, 2018).

Lebih lanjut hasil uji hipotesis H2a menyatakan bahwa kepercayaan tidak memoderasi dan memperkuat citra terhadap keberlanjutan usaha sehingga hipotesis penelitian ditolak. Hasil penelitian ini tidak mendukung literatur penelitian sebelumnya (Ariszani, Suharyono \& Kumadji, 2015; Damayanti, Fathorrahman \& Pradiani, 2020; Mardiana \& Rahmidani, 2020) yaitu citra baik mendatangkan pandangan positif yang kemudian berlanjut pada keputusan menggunakan jasa layanan oleh para jamaah. Kepercayaan tidak mampu memoderasi dengan memperkuat pengaruh citra terhadap keberlanjutan usaha, dikarenakan konsumen terkadang tidak mempedulikan citra yang dibangun biro perjalanan haji dan umrah, karena bagi jamaah dengan metode ketok tular dalam menggunakan jasa tersebut lebih dominan mempercayai informasi yang disampaikan oleh pihak sebelumnya (rekan atau saudara) yang telah menikmati jasa pelayanan dari perjalanan ibadah yang telah mereka lakukan. Fakta ini didukung dengan berbagai peristiwa yang terjadi dimana biro jasa yang memiliki citra dan reputasi baik banyak menipu para jamaahnya (Reza, 2020). Pada pengujian sebelumnya citra berkontribusi positif dan signifikan, untuk itu perusahaan sangat dianjurkan membangun citra baik yang positif terhadap jamaah, dengan disertai tujuan untuk memperoleh kepercayaan berupa keyakinan dan kenyamanan yang mendorong jamaah untuk memilih biro jasa perjalanan sehingga keberlanjutan usaha dapat tercapai (Dalimunthe, 2017; Widiastuti, 2019).

Kepercayaan juga tidak memoderasi dengan memperkuat promosi terhadap keberlanjutan usaha dan H3a ditolak, artinya hasil penelitian tidak mendukung dengan penelitian sebelumnya (Putra, 2016; Subardi, 2018; Damayanti, Fathorrahman \& Pradiani, 2020) yaitu menyatakan bahwa kepercayaan timbul karena penilaian yang positif terhadap suatu produk. Faktor ini terjadi karena 
disebabkan banyaknya kasus penipuan yang dilakukan oleh biro perjalanan haji dan umrah seperti First Travel, Asyifa Mandiri dan sebagainya (Reza, 2020) yang membuat para konsumen lebih berhati-hati dan tidak mudah mempercayai biro perjalanan haji dan umrah. Akibatnya keadaan ini membuat keberlanjutan usaha biro perjalanan haji dan umrah menjadi terancam, dimana arus kas penerimaan akan mengalami permasalahan dan terkendala dalam operasionalnya dan permasalahan keuangan yang berakibat pada kinerja keberlanjutan usaha (Mulyani, 2013). Walaupun promosi yang telah dilakukan secara besar-besaran akhirnya berakibat pula pada promosi yang tidak efektif, solusi berdasarkan pengamatan di lapangan adalah melakukan promosi secara ketok tular secara masif yang mengandalkan penyampaian informasi kepada calon jamaah yang akan memberikan dan menanamkan kepercayaan dengan pendekatan persuasif dari saudara, teman, sahabat yang telah menggunakan jasa biro perjalanan untuk mempromosikan lebih lanjut dengan berbagai insentif yang diberikan (Tajudin \& Mulazid, 2017; Santosa, Mahendra \& Haryanto, 2019).

Uji hipotesis penelitian H4a menyatakan bahwa kepercayaan memoderasi dengan memperkuat jaminan dari biro perjalanan terhadap keberlanjutan usaha sehingga $\mathrm{H} 4 \mathrm{a}$ diterima. Hasil penelitian didukung dengan penelitian sebelumnya (Setyawan \& Japarianto, 2014; Hasan \& Dana, 2018) yang menyatakan adanya keterkaitan kepastian dari keberangkatan ibadah terhadap keputusan memilih biro perjalanan yang akan meningkatkan arus kas positif sebagai kinerja perusahaan (Crisostomo, Freire \& Vasconcellos, 2011; Mulyani, 2013). Perbedaan antara hasil uji hipotesis H4 sebelumnya yang ditolak karena jaminan tidak berpengaruh terhadap keberlanjutan usaha biro perjalanan didasarkan fakta yang terjadi, adanya faktor kepercayaan yang meyakinkan jamaah melibatkan aspek pribadi khususnya, sosial dan budaya (Azyani, Sri susilawati \& Wijayanti, 2020) dibuktikan mampu memperkuat jamaah untuk memilih menggunakan biro perjalanan. Adanya jaminan terhadap kepastian keberangkatan ibadah haji dan umrah yang diberikan biro perjalanan dengan stimulan kepercayaan yang dilakukan dengan berbagai penjelasan dan perjanjian, dapat menimbulkan kepercayaan jamaah terhadap yang sangat mendukung pemilihan biro perjalanan haji dan umrah. Kepercayaan seharusnya dapat menjadi aspek yang menguntungkan bagi biro perjalanan haji dan umrah, karena kepercayaan dapat meningkatkan nilai ekonomi lebih jauh disebut margin keuntungan perusahaan atau dapat diperlakukan sebagai aset yang mendukung keberlanjutan dan pengembangan biro perjalanan haji dan umrah (Widiastuti, 2019) yang berkompetisi dengan biro perjalanan lainnya (Dalimunthe, 2017).

\section{KESIMPULAN DAN SARAN}

\section{Kesimpulan}

Hasil uji hipotesis penelitian pada model utama menyatakan bahwa tidak semua hipotesis yang dikemukakan dari model penelitian dapat diterima, yaitu pada hipotesis H4 yang menyatakan bahwa jaminan sebagai hal yang penting terhadap kepastian keberangkatan haji dan umrah ditolak sehingga tidak berpengaruh terhadap keberlanjutan usaha biro perjalanan haji dan umrah dan tidak mendukung 
penelitian sebelumnya. Uji hipotesis $\mathrm{H} 1, \mathrm{H} 2, \mathrm{H} 3$ dan $\mathrm{H} 5$ penelitian dapat diterima, hasil penelitian ini didukung penelitian sebelumnya, keseluruhan hasil memiliki kesesuaian pada fenomena dilapangan yang merupakan hasil observasi peneliti terhadap sejumlah objek dan unit analisis yang dieksplorasi pada penelitian ini.

Pengolahan data pada model modifikasi menggunakan variabel moderasi juga menunjukan bahwa tidak semua hipotesis yang dikemukakan dapat diterima, kepercayaan membuat faktor promosi dan citra menjadi tidak berpengaruh dan memperkuat keberlanjutan usaha dibandingkan dengan model utama sebelumnya. Promosi yang dilakukan dan citra yang positif yang dibangun tidak memoderasi dan memperkuat keberlanjutan usaha biro jasa perjalanan, karena saat ini banyak biro perjalanan yang mengingkari janji yang membuat jamaah calon haji dan umrah tidak dapat berangkat ibadah ke kota Suci Mekah, sehingga promosi yang dilakukan menjadi tidak efektif karena jamaah tidak memperoleh keyakinan dan kepastian.

\section{Keterbatasan}

Penelitian dengan menggunakan data kuesioner seringkali tidak dapat meyakinkan dikarenakan hanya mengandalkan persepsi, dan akhirnya menimbulkan beberapa kelemahan di antaranya subjektivitas yang tinggi, ketidakkonsistenan responden yang berpotensi terhadap kuesioner yang diisi akan berbeda dengan realita sesungguhnya. Daerah pengambilan sampel yang terbatas kurang mampu untuk menyimpulkan dari kasus penelitian ini secara keseluruhan, dan juga disertai kualifikasi para jamaah yang tidak semua berasal dari latar belakang pendidikan sarjana dan usia lanjut, menyebabkan pemahaman yang kurang maksimal dan memadai terhadap kuesioner yang diperoleh.

\section{Implikasi}

Referensi hasil penelitian ini memberikan informasi kepada perusahaan biro jasa perjalanan haji dan umrah dalam mempertahankan keberlanjutan usahanya dengan melakukan strategi penawaran produk jasa haji dan umrah, efektivitas promosi untuk membangun kepercayaan dan reputasi dilakukan dengan komunikasi persuasif ketok tular yang meningkatkan kepercayaan jamaah untuk memilih biro perjalanan, selain aspek lainnya yang dikaji dalam penelitian ini. Aspek teoritis yang dapat diberikan dari hasil penelitian adalah keberlanjutan usaha bukan hanya ditentukan berdasarkan variabel indpenden penelitian saja, namun dengan adanya kepercayaan sebagai moderasi menguatkan dan menentukan keberlanjutan usaha yang dibuktikan dengan nilai koefisien determinasi yang meningkat dari model utama ke model modifikasi.

\section{Saran}

Penelitian selanjutnya dapat dilakukan pada populasi yang lebih luas dengan meningkatkan jumlah sampel yang direncanakan lebih besar, selain itu peneliti selanjutnya juga dapat menambahkan variabel lainnya yang diprediksi mampu untuk memprediksi keberlanjutan usaha bagi biro jasa perjalanan dan umrah seperti : pelayanan, tarif, dan lain sebagainya. 


\section{DAFTAR PUSTAKA}

Akrout, H. (2019). Trust in buyer-supplier relationships: Evidence from advanced, emerging, and developing markets. Advances in Business Marketing and Purchasing, 26, pp. 1-5. doi: 10.1108/S1069-096420190000026004.

Andini, N., Suharyono and Sunarti. (2014). Pengaruh Viral Marketing Terhadap Kepercayaan Pelanggan Dan Keputusan Pembelian (Studi Pada Mahasiswa Fakultas Ilmu Administrasi Universitas Brawijaya Angkatan 2013 yang Melakukan Pembelian Online Melalui Media Sosial Instagram). Jurnal Administrasi Bisnis S1 Universitas Brawijaya, 11(1), p. 82726.

Arens, A. A. and Loebbecke, J. K. (1996). Auditing : Pendekatan Terpadu. Jakarta, Indonesia: Salemba Empat.

Ariszani, M., Suharyono and Kumadji, S. (2015). Pengaruh citra perusahaan terhadap kepercayaan serta dampaknya pada minat beli (studi kasus penjualan Online yang menggunakan Jasa Pengiriman JNE). Jurnal Administrasi Bisnis, 3(1), pp. 1-6.

Azyani, S., Srisusilawati, P. and Wijayanti, I. M. (2020) 'Analisis Keputusan Konsumen terhadap Pemilihan Travel Umroh Menggunakan Metode AHP'. Prosiding Hukum Ekonomi Syariah, 6(2), pp. 547-551.

Baker, J. and Wakefield, K. L. (2012). How consumer shopping orientation influences perceived crowding, excitement, and stress at the mall. Journal of the Academy of Marketing Science., 40(6), pp. 791-806. doi: 10.1007/s11747-011-0284-z.

Blombäck, A. and Scandelius, C. (2013). Corporate heritage in CSR communication: A means to responsible brand image?. Corporate Communications, 18(3), pp. 362-382. doi: 10.1108/CCIJ07-2012-0048.

Castro-gonz, S. and Fern, P. (2019). Responsible Leadership and Salespeople's Creativity: The Mediating Effects of CSR Perceptions. Sustainability. pp. 1-17. doi: 10.3390/su11072053.

Cervone, H. F. (2017). Implementing IT governance: a primer for informaticians. Digital Library Perspectives, 33(4). doi: 10.1108/DLP-07-2017-0023.

Couldry, N. and Powell, A. (2014). Big Data from the bottom up. Big Data and Society, 1(2), pp. 1-5. doi: $10.1177 / 2053951714539277$. 
Prihanto, H. \& Damayanti, P. (2022). Faktor-Faktor yang berpengaruh pada Keberlanjutan....

Crisostomo, V. L., Freire, F. de S. and Vasconcellos, F. C. de. (2011). Corporate social responsibility, firm value and financial performance in Brazil. Social Responsibility Journal, 7(2), pp. 295-309. doi: 10.1108/17471111111141549.

Dalimunthe, M. B. (2017). Keunggulan Bersaing Melalui Orientasi Pasar dan Inovasi Produk. Jurnal Konsep Bisnis dan Manajemen, 3(1).

Damayanti, S., Fathorrahman and Pradiani, T. (2020). Pengaruh Kepercayaan, Status Akreditasi Dan Strategi Promosi Terhadap Keputusan Mahasiswa Memilih Stikes Hafshawaty Pesantren Zainul Hasan Kabupaten Probolinggo. Jurnal Ekonomi Manajemen dan Bisnis, 1(1).

Damayanty, P. and Murwaningsari, E. (2020). The Role Analysis of Accrual Management on LossLoan Provision Factor and Fair Value Accounting to Earnings Volatility. Research Journal of Finance and Accounting, 11(2), pp. 155-162. doi: 10.7176/rjfa/11-2-16.

Faza, H. and Widiyanto, I. (2016). Studi Minat Mereferensikan Dalam Jasa Travel Umroh. Diponegoro Journal of Management, 5(1), pp. 1-15. Available at: http://ejournal-s1.undip.ac.id/index.php/dbr.

Fitzsimmons, J. A. and Mona, J. F. (2011). Service Management: Operations, Strategy, Information Technology 7th edition. The Mc.GrawHill Internation Edition.

Hakim, R. H. and Idris (2017). Analisis Faktor-Faktor yang Mempengaruhi Kepercayaan Konsumen Serta Implikasinya Terhadap Keputusan Pembelian ( Studi kasus pada Go-Ride di Kota Bandung ). Diponegoro Journal of Management, 6(1), pp. 1-11.

Halbouni, S. S., Obeid, N. and Garbou, A. (2016). Corporate governance and information technology in fraud prevention and detection. Managerial Auditing Journal, 31(6/7), p. .589-628. doi: 10.1108/MAJ-02-2015-1163.

Hasan, D. A. and Dana, I. M. (2018). Pengaruh Profitabilitas, Likuiditas, Maturity Dan Jaminan Terhadap Peringkat Obligasi Tertinggi Pada Sektor Keuangan Di Bursa Efek Indonesia. E-Jurnal Manajemen Unud, 7(2), pp. 643-673.

Hendro. (2011). Dasar-dasar Kewirausahaan. Jakarta, Indonesia: Erlangga.

Hong, Y. and Andersen, M. L. (2011). The Relationship Between Corporate Social Responsibility and Earnings Management: An Exploratory Study. Journal of Business Ethics, 104(4), pp. 461-471. doi: 10.1007/s10551-011-0921-y.

Kourula, A. and Delalieux, G. (2016). The Micro-level Foundations and Dynamics of Political 
Corporate Social Responsibility: Hegemony and Passive Revolution through Civil Society. Journal of Business Ethics, 135(4), pp. 769-785. doi: 10.1007/s10551-014-2499-7.

Mahrani, M. and Soewarno, N. (2018). The effect of good corporate governance mechanism and corporate social responsibility on financial performance with earnings management as mediating variable. Asian Journal of Accounting Research, 3(1), pp. 41-60. doi: 10.1108/AJAR-06-20180008 .

Mardiana, F. and Rahmidani, R. (2020). Pengaruh Harga, Kepercayaan dan Citra Perusahaan Terhadap Loyalitas Pelanggan Perusahaan Otobus Kurnia (PO. Kurnia) Rute Padang-Medan. E-Jurnal Ekonomi dan Bisnis Universitas Udayana, 3(2), pp. 232-241. doi: 10.24843/eeb.2018.v07.i07.p03.

McCarter, M. W., Mahoney, J. T. and Northcraft, G. B. (2011). Testing the waters: Using collective real options to manage the social dilemma of strategic alliances. Academy of Management Review, 36(4), pp. 621-640. doi: 10.5465/amr.2009.0481.

Mulyani, S. (2013). Analisis Rasio Arus Kas Sebagai Alat Pengukur Kinerja Keuangan Perusahaan. 18 Jurnal Dinamika Ekonomi \& Bisnis, 10(1), pp. 96-124. Available at: http://journal.unj.ac.id/unj/index.php/jrmsi.

Ningrum, D. A. (2018). 4 Kasus travel umroh yang mengguncang Indonesia. Merdeka.com, March. Available at: https://www.merdeka.com/peristiwa/4-kasus-travel-umroh-yang-mengguncangindonesia.html.

Oliver, B. B., Florack, A. and Goritz, A. S. (2013). Shopping Orientation and Mindsets : How Motivation Influences Consumer Information Processing During. Psychology \& Marketin, 30(9), pp. 779-793. doi: 10.1002/mar.

Phillip, K. and Keller, K. L. (2012). Marketing Management 14th edition. Jakarta: PT. Indeks Kelompok Gramedia.

Prihanto, H. (2018). Etika Bisnis dan Profesi: Sebuah Pencarian. Depok: Rajawali Pers.

Prihanto, H. and Damayanti, P. (2020). Disclosure Information on Indonesian UMKM Taxes. Jurnal Riset Akuntansi dan Keuangan, 8(3), pp. 447-454. doi: 10.17509/jrak.v8i3.26707.

Prihanto, H. and Gunawan, I. D. (2020). Corruption in Indonesia (Is It Right to Governance, Leadership and It to Be Caused?). Journal of Economics and Sustainable Development, 11(2), pp. 56-65. 
Prihanto, H. \& Damayanti, P. (2022). Faktor-Faktor yang berpengaruh pada Keberlanjutan....

Putra, E. (2016). Pengaruh Promosi dan Kepercayaan Merek dan Terhadap Keputusan Pembelian Sepeda Motor Yamaha Di Pasaman Barat. e-Jurnal Apresiasi Ekonomi, 4(3), pp. 165-168.

Putri, R. W., Suharyono and Fanani, D. (2015). Pengaruh Kualitas Pelayanan Terhadap Kepuasan dan Loyalitas. Jurnal Administrasi Bisnis (JAB), 1(1).

Quazi, A. and Richardson, A. (2012). Sources of variation in linking corporate social responsibility and financial performance. Social Responsibility Journal, 8(2), pp. 242-256. doi: 10.1108/17471111211234860.

Razafindrambinina, D. and Sabran, A. (2014). The Impact of Strategic Corporate Social Responsibility on Operating Performance: An Investigation Using Data Envelopment Analysis in Indonesia. Journal of Business Studies Quarterly, 6(1).

Reza, T. (2020). Waspada Maraknya Penipuan Biro Umroh. Kompas TV, February. Available at: https://www.kompas.tv/article/66946/waspada-maraknya-penipuan-biro-umroh.

Roslina. (2010). Citra Merek: Dimensi, Proses Pengembangan Serta Pengukurannya. Jurnal Bisnis dan Manajemen, 6(3), pp. 333-346.

Saikouk, T. et al. (2021). The interplay between inter-personal and inter-organizational relationships in coordinating supply chain activities. The International Journal of Logistics Management, aheadof-p(ahead-of-print). doi: 10.1108/ijlm-11-2020-0443.

Santosa, J., Mahendra, D. and Haryanto, A. T. (2019). Pengaruh Kepercayaan, Promosi Dan Kualitas Produk Terhadap Kepuasan Dan Loyalitas Nasabah Tabungan Pada Pd Bpr Bank Daerah Klaten. Excellent, 6(2), pp. 124-135. doi: 10.36587/exc.v6i2.591.

Saputri, D. P. O. S. and Purbawangsa, I. B. A. (2016). Pengaruh Leverage, Profitabilitas, Pertumbuhan Perusahaan, Dan Jaminan Terhadap Peringkat Obligasi Sektor Jasa Di Bursa Efek Indonesia. EJurnal Manajemen Unud, 5(6), pp. 3706-3735.

Setyawan, Y. N. and Japarianto, E. (2014). Analisa Pengaruh Kepercayaan, Jaminan Rasa Aman , dan Aksesbilitas terhadap Minat Menabung Nasabah Bank Danamon di Surabaya. Jurnal Manajemen Pemasaran Petra, 2(1), pp. 1-8.

Silvola, H. and Vinnari, E. (2021). The limits of institutional work: a field study on auditors' efforts to promote sustainability assurance in a trust society. Accounting, Auditing and Accountability Journal, 34(1), pp. 1-30. doi: 10.1108/AAAJ-02-2019-3890. 
Subardi, L. (2018). Pengaruh Promosi dan Kepercayaan Nasabah Terhadap Keputusan Penggunaan Layanan Digital di Bank Sumsel Babel Cabang Prabumulih. JEMG; Jurnal Ecoment Global, 3 , pp. 183-197.

Tajudin, M. H. and Mulazid, A. S. (2017). Pengaruh Promosi, Kepercayaan dan Kesadaran Merk Terhadap Keputusan Nasabah Menggunakan Tabungan Haji (Mabrur) Bank Syariah Mandiri KPC. Sawangan Kota Depok. Islamiconomic: Jurnal Ekonomi Islam, 8(1), pp. 19-46.

Umar, H. (2016). Corruption The Devil. Jakarta: Universitas Trisakti.

Umar, I. U., Shamsudin, R. S. and Mohamed, B. M. (2017). Article information: Ascertaining the Effectiveness of Economic and Financial Crimes Commission ( EFCC) in Tackling Corruptions in Nigeria. Journal of Financial Crime.

Uwuigbe, U., Sunday, D. and Oyeniyi, A. (2014). The effects of corporate governance mechanisms on earnings management of listed firms in Nigeria Abstract. Accounting and Management Information Systems, 13(1), pp. 159-174.

Villena, V. H., Revilla, E. and Choi, T. Y. (2011). The dark side of buyer-supplier relationships: A social capital perspective. Journal of Operations Management, 29(6), pp. 561-576. doi: 10.1016/j.jom.2010.09.001.

Wahyuni Mardiana, I. and Hariyati. (2014). Pengaruh Modal Manusia, Modal Struktural, Dan Modal Pelanggan Terhadap Kinerja Bisnis. Jurnal Ilmu Manajemen, 2(2), pp. 623-635.

Wicks, A. C. and Harrison, J. S. (2017). Toward a More Productive Dialogue between Stakeholder Theory and Strategic Management. Stakeholder Management, pp. 249-273. doi: 10.1108/s2514175920170000012.

Widiastuti, E. (2019). Peningkatan Pengetahuan, Ketrampilan Dan Kemampuan Sumber Daya Manusia Sebagai Strategi Keberlangsungan Usaha Pada Umkm Batik Di Kabupaten Banyumas. Jurnal Ekonomi, Bisnis, dan Akuntansi (JEBA), 21(01). www.journal.uta45jakarta.ac.id.

Zainal, V. . et al. (2017). Islamic Marketing Management. Jakarta: Bumi Aksara.

Zulkifli, B., Shokiyah, A. and Mohd Serjana, I. (2014). Factors that contribute to the effectiveness of internal audit in public sector. International Proceedings of Economics Development And Research. The Citiview. 